\title{
ANALISIS MODAL KERJA \\ PADA KOPERASI SERBA USAHA DI KOTA METRO
}

\author{
Kuncoro Budi Riyanto
}

Phone.085279226535, e-mail: kuncoro1906@gmail.com

Muhammadiyah University of Metro City, 34111, Indonesia

\section{FIDUSIA}

Jurnal Ilmiah Keuangan dan Perbankan

ISSN Cetak : 2621-2439

ISSN Online : 2621-2447

Kata kunci : Modal kerja, sumber dan pengunaan dana.

\begin{abstract}
ABSTRAK
Modal kerja merupakan suatu kekayaan yang digunakan untuk membelanjai perusahaan sehari-hari. Modal kerja biasanya berbentuk uang kas, piutang, persediaan barang yang kesemuanya itu masuk dalam struktur neraca aktiva lancar. Tujuan penelitian ini adalah untuk mengetahui efisiensi sumber modal kerja pada koperasi serba usaha jurai siwo pada tahun 2010 s/d 2014. Dan untuk mengetahui perubahan-perubahan yang terjadi pada posisi modal kerja pada tahun $2010 \mathrm{~s} / \mathrm{d}$ 2014

Berdasarkan hasil penelitian analisis laporan sumber dan penggunaan modal kerja pada KSU “JUSI” pada periode 2010-2011 mengalami kenaikan modal kerja sebesar Rp. 136.250.257,0. Pada periode 2011-2012 mengalami penurunan modal kerja sebesar Rp. 192.238.816,00. Pada periode 2012-2013 KSU “JUSI” mengalami penurunan modal kerja kembali sebesar Rp. 2.136.997.717,00. KSU “JUSI” pada periode 2013-2014 mengalami penurunan modal kerja sebesar Rp. 1.881.785.781,00.

Berdasarkan analisis laporan sumber dan penggunaan modal kerja pada KSU “JUSI" perubahan-perubahan yang terjadi pada posisi modal kerja periode 2010-2011 yakni SHU Tahun 2011 sebesar Rp. 766.300.817,00 dan sumber modal yang terendah berasal dari berkurangnya simpanan pokok sebesar Rp. 1.195.000,00. Penggunaan modal kerja yang paling besar adalah penurunan SHU Tahun 2010 Rp. 729.873.299,00 dan disusul oleh pelunasan hutang BSM sebesar Rp. 931.791.904,00.

Pada periode 2011-2012 sumber modal kerja berasal dari penjualan kendaraan sebesar Rp. 3.050.000,00 dan dari hasil operasi KSU “JUSI” sebesar Rp. 766.300.817,00 sumber modal yang utama berasal dari hutang pembiayaan BSM sebesar Rp. 1.095.141.093,00 . penggunaan modal kerja yang utama berasal dari kerugian SHU Tahun 2012 sebesar Rp. 786.558.737.

Periode 2012-2013 sumber modal yang mendominasi adalah pelunasan hutang BSM sebesar Rp. 2.828.765.060,00 Penggunaan modal kerja yang terbesar berasal karena bertambahnya bangunan dan inventaris kantor sebesar Rp. 4.363.052.508,00 dan kerugian SHU Tahun 2013 sebesar Rp. 763.812.676,00. Pada periode tahun 2013-2014 sumber modal berasal dari pelunasan hutang BSM sebesar Rp. 2.463.154.171 sedangkan sumber modal yang terendah berasal dari berkurangnya aktiva lain-lain sebesar Rp. 8.337.499,00. Penggunaan modal yang terbesar perenovasian bangunan dan pembaharuan peralatan kantor dan kerugian tahun sebelumnya.
\end{abstract}

Kata kunci : Modal kerja, sumber dan pengunaan dana. 


\section{PENDAHULUAN}

Perkembangan banyak usaha koperasi yang tidak mampu melanjutkan usahanya yang disebabkan oleh kurang baiknya kemampuan untuk mengembangkan usahanya dengan baik. Baik tidaknya koperasi tersebut dalam mempertahankan kelangsungan hidupnya dapat dilihat dari kemampuan kinerja keuangannya.

Koperasi selalu mengeluarkan laporan keuangan secara periodik yang dibuat oleh bagian keuangan dan dibagikan kepada pihak-pihak yang berkepentingan (Pemerintah, Kreditor, Pemilik Perusahaan, dan Pihak Manajemen). Laporan keuangan berguna untuk mengetahui hasil yang dicapai pada suatu periode akuntansi. Peran laporan keuangan sangat penting dalam mengukur perkembangan koperasi yang meliputi kemajuan dan kelancaran koperasi tersebut. Umumnya laporan keuangan koperasi dibukukan dalam buku laporan pertanggungjawaban pengurus koperasi yang dibagikan kepada setiap anggota koperasi pada Rapat Anggota Tahunan (RAT) dalam bentuk neraca, Perhitungan Sisa Hasil Usaha (SHU), dan sebagainya.

Salah satu metode yang digunakan dalam menganalisis laporan keuangan adalah dengan menggunakan analisis sumber dan penggunaan modal kerja. Analisis ini merupakan alat analisa finansial yang sangat penting, di samping alat-alat lainnya. Maksud utama dari analisis sumbersumber dan penggunaan dana adalah untuk mengetahui bagaimana dana digunakan dan bagaimana kebutuhan dana tersebut dibelanjai. Dengan kata lain dengan analisis ini akan dapat diketahui dari mana sumber dana dan untuk apa dana tersebut digunakan (Riyanto, 2010:345). Analisis tersebut dibuat karena merupakan salah satu faktor yang menunjukkan kemajuan, kelancaran koperasi dan mengetahui keberhasilan pencapaian tujuan koperasi.

Analisis sumber dan penggunaan modal kerja atau sering disebut analisa aliran dana, merupakan alat analisa finansial yang sangat penting bagi pimpinan perusahaan disamping alat finansial lainnya. Maksud utama dari analisa tersebut adalah untuk mengetahui bagaimana dana digunakan dan bagaimana kebutuhan tersebut dibelanjai. Dengan kata lain analisa aliran dana dapat diketahui dari mana datangnya dana dan untuk apa dana itu digunakan. (Riyanto, 2010:345)

Modal kerja sangat penting dalam perusahaan yang digunakan untuk pembelanjaan kegiatan operasionalnya sehari-hari. Modal kerja yang terlalu besar memungkinkan terjadinya dana yang menganggur (idle fund). Hal ini akan mengakibatkan infisien. Demikian sebaliknya modal kerja yang terlalu kecil mengakibatkan terganggunya proses operasional koperasi sehari-hari, dengan demikian menggunakan modal kerja serta elemen modal kerja.

Tabel 1. Rasio Lancar dari Tahun 2010 Sampai Tahun 2014

\begin{tabular}{|c|c|c|c|}
\hline Tahun & Aktiva Lancar(Rp) & Hutang lancar(Rp) & Current Ratio \\
\hline 2010 & 14.506 .517 .722 & 11.133 .405 .745 & $130 \%$ \\
\hline 2011 & 14.298 .250 .855 & 10.574 .776 .438 & $135 \%$ \\
\hline 2012 & 13.386 .509 .598 & 9.311 .412 .323 & $143 \%$ \\
\hline 2013 & 11.204 .983 .344 & 6.818 .459 .485 & $164 \%$ \\
\hline 2014 & 9.247 .920 .758 & 4.680 .639 .620 & $197 \%$ \\
\hline
\end{tabular}

Sumber: Koperasi Serba Usaha Jurai Siwo 
Berdasarkan Tabel 1 dapat diketahui kemampuan koperasi dalam membayar kewajiban lancar setiap tahunnya (current ratio). Koperasi Serba Usaha Jurai Siwo (KSU “JUSI") pada tahun 2010 sebesar 130\% Hal ini berarti setiap Rp 1,00 Hutang Lancar dijamin dengan Aktiva lancar sebesar Rp 1,30. Nilai current ratio (CR) dari tahun 2010 sampai dengan 2014 yang cenderung mengalami peningkatan rata-rata $153 \%$ ini menggambarkan bahwa setiap tahunnya aktiva lancar mampu menjamin hutang lancar dengan lebih baik. Namun demikian dilihat dari aktiva lancar, KSU "JUSI" selama 5 tahun terakhir ini cenderung mengalami penurunan.

Berikut ini perkembangan modal kerja KSU'JUSI" tahun 2010 sampai dengan tahun 2014:

Tabel 2. Perkembangan Modal Kerja 2010 - 2014 (Dalam Rupiah)

\begin{tabular}{|c|c|c|c|}
\hline Tahun & Aktiva Lancar(Rp) & Hutang lancer(Rp) & Modal Kerja(Rp) \\
\hline 2010 & 14.506 .517 .722 & 11.133 .405 .745 & 3.373 .111 .977 \\
\hline 2011 & 14.298 .250 .855 & 10.574 .776 .438 & 3.723 .474 .417 \\
\hline 2012 & 13.386 .509 .598 & 9.311 .412 .323 & 4.075 .097 .275 \\
\hline 2013 & 11.204 .983 .344 & 6.818 .459 .485 & 4.386 .523 .859 \\
\hline 2014 & 9.247 .920 .758 & 4.680 .639 .620 & 4.567 .281 .138 \\
\hline
\end{tabular}

Sumber :Koperasi Serba Usaha Jurai Siwo

Dari tabel 2 dapat dijelaskan bahwa perkembangan modal kerja KSU"JUSI" Kota Metro dari tahun 2010 sampai tahun 2014 mengalami peningkatan. Pada tahun 2010 sampai 2011 sebesar 11\%, pada tahun 2012 sebesar 10,9\%. Pada tahun 2013 sebesar 10,7\% sedangkan pada tahun 2014 sebesar 10,4\%. Berdasarkan uraian latar belakang penelitian dan perumusan identifikasi masalah, maka Apakah posisi sumber \& penggunaan modal kerja Koperasi Jurai Siwo sudah efisien?

\section{Tujuan Penelitian}

Berdasarkan latar belakang penelitian dan perumusan masalah di atas maka tujuan penelitian ini adalah untuk mengetahui efisiensi sumber modal kerja dan untuk menganalisis perubahanperubahan yang terjadi pada posisi modal kerja pada KSU Jurai Siwo tahun 2010 - 2014.

\section{KAJIAN TEORI}

Koperasi adalah suatu usaha yang dilakukan oleh sekelompok orang dengan prinsip kebersamaan untuk mencapai tujuan memenuhi kebutuhan (Teguh Sihono, 1999:46). Sedangkan Koperasi Serba Usaha (KSU) adalah koperasi yang kegiatan ekonominya lebih dari satu bidang usaha seperti; perkreditan, penyediaan dan penyaluran sarana produksi dan keperluan sehari-hari, dan pengelolaan serta pemasaran hasil.

Modal kerja merupakan dana yang digunakan untuk membiayai operasional perusahaan, terutama yang memiliki jangka waktu yang pendek. Modal kerja diartikan seluruh aktiva lancar atau setelah dikurangi utang lancar (Kasmir, 2012:249). 
Maksud utama dari analisis sumber-sumber dan penggunaan dana adalah untuk mengetahui bagaimana dana digunakan dan bagaimana kebutuhan dana tersebut dibelanjai dengan kata lain dengan analisis aliran dana itu akan dapet diketahui dari mana datangnya dana dan untuk apa dana digunakan, Riyanto, (2010:345).

\section{METODE PENELITIAN}

Jenis penelitian yang dilakukan adalah penelitian kualitatif yaitu penelitian tentang riset yang bersifat deskriptif dan cenderung menggunakan analisis. Penelitian ini dilakukan dengan cara mengumpulkan data laporan keuangan yang ada pada KSU Jurai Siwo. Metode penelitian yang digunakan penulis dalam penelitian ini adalah penelitian deskriptif (descriptive research).

Sumber data dalam penelitian ini diperoleh dari data sekunder yaitu laporan keuangan KSU “JUSI" di Kota Metro Lampung periode 2009-2013. Teknik pengumpulan data dalam penelitian ini menggunakan interview (wawancara), observasi, dokumentasi, dan kepustakaan (library research). Analisis data yang digunakan dalam penelitian ini yaitu analisis data kuantitatif dan kualitatif.

\section{PEMBAHASAN}

Laporan perubahan posisi keuangan memberikan perkiraan tentang hasil aktivitas keuangan suatu perusahaan selama satu tahun. Laporan perubahan neraca menggambarkan perubahan dari setiap elemen dan perkiraan dari dua titik waktu tersebut. Dengan demikian, dari setiap perubahan mencerminkan adanya sumber dan penggunaan modal dengan bantuan laporan rugi/laba. Berikut ini disajikan laporan perubahan posisi keuangan KSU "Jurai Siwo":

Tabel 3. Laporan Perubahan Posisi Keuangan KSU “JUSI” (Dalam Rupiah)

Periode 2010-2011

\begin{tabular}{|l|r|r|r|r|}
\hline \multirow{2}{*}{ KETERANGAN } & \multicolumn{2}{|c|}{ TAHUN } & \multicolumn{2}{c|}{ PERUBAHAN } \\
\cline { 2 - 5 } $\begin{array}{l}\text { HARTA } \\
\text { LANCAR }\end{array}$ & & $\mathbf{2 0 1 0}$ & \multicolumn{1}{c|}{ DEBIT } & KREDIT \\
\hline Kas & $266.031 .941,00$ & $497.628 .980,00$ & & \\
\hline Bank & $128.040 .131,00$ & $930.008 .331,00$ & & $231.597 .039,00$ \\
\hline Piutang & $13.810 .217 .135,00$ & $12.571 .232 .230,00$ & $1.238 .984 .905,00$ & \\
\hline $\begin{array}{l}\text { Cadangan } \\
\text { Penyisihan Piutang }\end{array}$ & $76.470 .340,00$ & $73.022 .040,00$ & $3.448 .300,00$ & \\
\hline $\begin{array}{l}\text { Piutang Akte } \\
\text { Tanah }\end{array}$ & $7.000 .000,00$ & $5.000 .000,00$ & $2.000 .000,00$ & \\
\hline Persediaan Barang & $37.392 .247,00$ & $35.997 .631,00$ & $1.394 .616,00$ & \\
\hline $\begin{array}{l}\text { Persediaan Kapling } \\
\text { Tanah }\end{array}$ & $30.000 .000,00$ & $30.000 .000,00$ & & \\
\hline $\begin{array}{l}\text { Biaya Dibayar } \\
\text { Dimuka }\end{array}$ & $23.015 .500,00$ & $15.345 .500,00$ & $7.670 .000,00$ & \\
\hline $\begin{array}{l}\text { Jumlah Harta } \\
\text { Lancar }\end{array}$ & $\mathbf{1 4 . 2 2 5 . 2 2 6 . 6 1 4 , 0 0}$ & $\mathbf{1 4 . 0 1 2 . 1 9 0 . 6 3 2 , 0 0}$ & & \\
\hline
\end{tabular}




\begin{tabular}{|l|r|r|r|r|} 
HARTA TETAP & & & \\
\hline Bangunan & $50.060 .296,00$ & $43.952 .246,00$ & & $6.108 .050,00$ \\
\hline Kendaraan & $8.100 .009,00$ & $5.400 .008,00$ & & $2.700 .009,00$ \\
\hline Peralatan Kantor & $103.611 .092,00$ & $86.892 .256,00$ & & $16.718 .836,00$ \\
\hline Perlengkapan & 6,00 & 6,00 & & \\
\hline Aktiva lain-lain & $119.519 .705,00$ & $149.815 .707,00$ & $30.296 .002,00$ & \\
\hline $\begin{array}{l}\text { Jumlah Harta } \\
\text { Tetap }\end{array}$ & $\mathbf{2 8 1 . 2 9 1 . 1 0 8 , 0 0}$ & $\mathbf{2 8 6 . 0 6 0 . 2 2 3 , 0 0}$ & $4.769 .115,00$ & \\
\hline $\begin{array}{l}\text { JUMLAH } \\
\text { HARTA/AKTIVA }\end{array}$ & $\mathbf{1 4 . 5 0 6 . 5 1 7 . 7 2 2 , 0 0}$ & $\mathbf{1 4 . 2 9 8 . 2 5 0 . 8 5 5 , 0 0}$ & & \\
\hline & & & & \\
\hline $\begin{array}{l}\text { HUTANG } \\
\text { LANCAR }\end{array}$ & & & & \\
\hline $\begin{array}{l}\text { Hutang Jangka } \\
\text { Pendek }\end{array}$ & & & & \\
\hline Dana Pendidikan & $141.546 .093,00$ & $153.039 .758,00$ & & $11.493 .665,00$ \\
\hline $\begin{array}{l}\text { Dana Pemb. } \\
\text { Daerah Kerja }\end{array}$ & $123.366 .456,00$ & $141.613 .286,00$ & & \\
\hline Dana Sosial & $50.284 .240,00$ & $53.830 .070,00$ & & \\
\hline $\begin{array}{l}\text { Hutang Biaya } \\
\text { Investasi }\end{array}$ & $2.000 .000,00$ & & & \\
\hline Cadangan Khusus & & $52.396 .000,00$ & & \\
\hline $\begin{array}{l}\text { Jumlah Hutang J. } \\
\text { Pendek }\end{array}$ & $\mathbf{3 1 7 . 1 9 6 . 7 8 9 , 0 0}$ & $\mathbf{4 0 0 . 8 7 9 . 1 1 4 , 0 0}$ & & \\
\hline $\begin{array}{l}\text { Hutang Jangka } \\
\text { Panjang }\end{array}$ & & & & \\
\hline $\begin{array}{l}\text { Hutang } \\
\text { Pembiayaan BSM }\end{array}$ & $8.854 .811 .747,00$ & $7.923 .019 .843,00$ & $931.791 .904,00$ & \\
\hline $\begin{array}{l}\text { Simpanan Khusus } \\
\text { Anggota }\end{array}$ & $1.961 .397 .209,00$ & $2.250 .877 .481,00$ & & \\
\hline $\begin{array}{l}\text { Jumlah Hutang J. } \\
\text { Panjang }\end{array}$ & $\mathbf{1 0 . 8 1 6 . 2 0 8 . 9 5 6 , 0 0}$ & $\mathbf{1 0 . 1 7 3 . 8 9 7 . 3 2 4 , 0 0}$ & & \\
\hline
\end{tabular}

Lanjutan Tabel 3. Laporan Perubahan Posisi Keuangan KSU “JUSI" (Dalam Rupiah) Periode 2010-2011

\begin{tabular}{|l|r|r|r|r|}
\hline KEKAYAAN & & & & \\
\hline Simpanan Pokok & $45.291 .000,00$ & $46.486 .000,00$ & & $1.195 .000,00$ \\
\hline Simpanan Wajib & $420.170 .250,00$ & $440.960 .850,00$ & & $375.209 .400,00$ \\
\hline Donasi & $195.135 .132,00$ & $195.135 .132,00$ & & \\
\hline Cadangan & $1.982 .642 .296,00$ & $2.274 .591 .618,00$ & & $291.949 .322,00$ \\
\hline SHU Tahun 2010 & $729.873 .299,00$ & & $729.873 .299,00$ & \\
\hline SHU Tahun 2011 & & $766.300 .817,00$ & & $766.300 .817,00$ \\
\hline Jumlah Kekayaan & $\mathbf{3 . 3 7 3 . 1 1 1 . 9 7 7 , 0 0}$ & $\mathbf{3 . 7 2 3 . 4 7 4 . 4 1 7 , 0 0}$ & & \\
\hline $\begin{array}{l}\text { JUMLAH } \\
\text { HUTANG/PASIVA }\end{array}$ & $\mathbf{1 4 . 5 0 6 . 5 1 7 . 7 2 2 , 0 0}$ & $\mathbf{1 4 . 2 9 8 . 2 5 0 . 8 5 5 , 0 0}$ & & \\
\hline TOTAL & & & $2.952 .228 .141,00$ & $2.952 .228 .141,00$ \\
\hline
\end{tabular}

Sumber: Laporan Keuangan KSU”JUSI” (data diolah) 
Tabel 4. Laporan Perubahan Modal Kerja KSU “JUSI" (Dalam Rupiah) Periode 2010-2011

\begin{tabular}{|c|c|c|c|c|}
\hline \multirow{2}{*}{ KETERANGAN } & \multicolumn{2}{|c|}{ TAHUN } & \multicolumn{2}{|c|}{ MODAL KERJA } \\
\hline & 2010 & 2011 & NAIK & TURUN \\
\hline \multicolumn{5}{|l|}{ HARTA LANCAR } \\
\hline Kas & $266.031 .941,00$ & $497.628 .980,00$ & & $231.597 .039,00$ \\
\hline Bank & $128.040 .131,00$ & $930.008 .331,00$ & & $801.968 .200,00$ \\
\hline Piutang & $13.810 .217 .135,00$ & $12.571 .232 .230,00$ & 1238984905 & \\
\hline $\begin{array}{l}\text { Cadangan Penyisihan } \\
\text { Piutang }\end{array}$ & $76.470 .340,00$ & $73.022 .040,00$ & 3448300 & \\
\hline Piutang Akte Tanah & $7.000 .000,00$ & $5.000 .000,00$ & 2000000 & \\
\hline Persediaan Barang & $37.392 .247,00$ & $35.997 .631,00$ & 1394616 & \\
\hline $\begin{array}{l}\text { Persediaan Kapling } \\
\text { Tanah }\end{array}$ & $30.000 .000,00$ & $30.000 .000,00$ & & \\
\hline $\begin{array}{l}\text { Biaya Dibayar } \\
\text { Dimuka }\end{array}$ & $23.015 .500,00$ & $15.345 .500,00$ & 7670000 & \\
\hline $\begin{array}{l}\text { Jumlah Harta } \\
\text { Lancar }\end{array}$ & 14.225.226.614,00 & 14.012.190.632,00 & & \\
\hline \multicolumn{5}{|l|}{ HUTANG LANCAR } \\
\hline \multicolumn{5}{|l|}{ Hutang j. Pendek } \\
\hline Dana Pendidikan & $141.546 .093,00$ & $153.039 .758,00$ & & $11.493 .665,00$ \\
\hline $\begin{array}{l}\text { Dana Pemb. Daerah } \\
\text { Kerja }\end{array}$ & $123.366 .456,00$ & $141.613 .286,00$ & & $18.246 .830,00$ \\
\hline Dana Sosial & $50.284 .240,00$ & $53.830 .070,00$ & & $3.545 .830,00$ \\
\hline $\begin{array}{l}\text { Hutang Biaya } \\
\text { Investasi }\end{array}$ & $2.000 .000,00$ & & 2000000 & \\
\hline Cadangan Khusus & & $52.396 .000,00$ & & $52.396 .000,00$ \\
\hline $\begin{array}{l}\text { Jumlah Hutang J. } \\
\text { Pendek }\end{array}$ & 317.196.789,00 & 400.879.114,00 & & \\
\hline Total & & & 1255497821 & $119.247 .564,00$ \\
\hline kenaikan modal & & & & $136.250 .257,00$ \\
\hline
\end{tabular}

Sumber: Laporan Keuangan KSU “JUSI” (data diolah) 
Tabel 5. Laporan Sumber dan Penggunaan Modal Kerja KSU “JUSI” (Dalam Rupiah) Periode 2010-2011

\begin{tabular}{|l|r|l|r|}
\hline SUMBER & TUNAI & PENGGUNAAN & TUNAI \\
\hline $\begin{array}{l}\text { berkurangnya biaya } \\
\text { bangunan }\end{array}$ & 6108050 & bertambahnya aktiva lain-lain & 30296002 \\
\hline penjualan kendaraan & 2700009 & berkurangnya INVENTARIS & 4769115 \\
\hline penjualan peralatan kantor & 16718836 & berkurangnya hutang BSM & 931791904 \\
\hline $\begin{array}{l}\text { berkurangnya khusus } \\
\text { anggota }\end{array}$ & 289480272 & penurunan SHU tahun 2010 & 729873299 \\
\hline berkurangnya simp. Pokok & 1195000 & & \\
\hline berkurangnya simp. Wajib & 375209400 & & \\
\hline $\begin{array}{l}\text { berkurangnya dana } \\
\text { cadangan }\end{array}$ & 291949322 & & 1613411449 \\
\hline SHU TAHUN 2011 & 766300817 & & 136250257 \\
\hline Jumlah & 1749661706 & jumlah & 1749661706 \\
\hline kenaikan modal kerja & & & \\
\hline TOTAL & 1749661706 & & \\
\hline
\end{tabular}

Sumber: Laporan Keuangan KSU “JUSI” (data diolah)

Tabel 6. Laporan Perubahan Posisi Keuangan KSU "JUSI" (Dalam Rupiah)

Tahun 2011-2012

\begin{tabular}{|c|c|c|c|c|}
\hline \multirow{2}{*}{ KETERANGAN } & \multicolumn{2}{|c|}{ TAHUN } & \multicolumn{2}{|c|}{ PERUBAHAN } \\
\hline & 2011 & 2012 & DEBIT & KREDIT \\
\hline \multicolumn{5}{|l|}{ HARTA LANCAR } \\
\hline Kas & $497.628 .980,00$ & $87.212 .225,00$ & & $410.416 .755,00$ \\
\hline Bank & $930.008 .331,00$ & $650.627 .321,00$ & & $279.381 .010,00$ \\
\hline Piutang & $12.571 .232 .230,00$ & $12.180 .825 .330,00$ & & $390.406 .900,00$ \\
\hline $\begin{array}{l}\text { Cadangan Penyisihan } \\
\text { Piutang }\end{array}$ & $73.022 .040,00$ & $56.877 .366,00$ & $16.144 .674,00$ & \\
\hline Piutang Akte Tanah & $5.000 .000,00$ & $1.400 .000,00$ & & $3.600 .000,00$ \\
\hline Persediaan Barang & $35.997 .631,00$ & $35.497 .458,00$ & & $500.173,00$ \\
\hline $\begin{array}{l}\text { Persediaan Kapling } \\
\text { Tanah }\end{array}$ & $30.000 .000,00$ & $30.000 .000,00$ & 0,00 & \\
\hline $\begin{array}{l}\text { Biaya Dibayar } \\
\text { Dimuka }\end{array}$ & $15.345 .500,00$ & $7.672 .750,00$ & & $7.672 .750,00$ \\
\hline $\begin{array}{l}\text { Jumlah Harta } \\
\text { Lancar }\end{array}$ & 14.012.190.632,00 & 12.936.357.718,00 & & \\
\hline \multicolumn{5}{|l|}{ HARTA TETAP } \\
\hline Tanah & $70.000 .000,00$ & $70.000 .000,00$ & 0,00 & \\
\hline Bangunan & $44.005 .448,00$ & $185.367 .898,00$ & $141.362 .450,00$ & \\
\hline Kendaraan & $6.800 .008,00$ & $3.750 .008,00$ & & $3.050 .000,00$ \\
\hline $\begin{array}{l}\text { Peralatan Kantor dan } \\
\text { Toko }\end{array}$ & $121.842 .268,00$ & $125.508 .974,00$ & 3.666.706,00 & \\
\hline Aktiva lain-lain & $43.412 .500,00$ & $65.525 .000,00$ & $22.112 .500,00$ & \\
\hline Jumlah Harta Tetap & $286.060 .224,00$ & 450.151.880,00 & & \\
\hline $\begin{array}{l}\text { JUMLAH } \\
\text { HARTA/AKTIVA }\end{array}$ & 14.298.250.856,00 & 13.386.509.598,00 & & \\
\hline
\end{tabular}


Lanjutan Tabel 6. Laporan Perubahan Posisi Keuangan KSU “JUSI” Tahun 2011-2012

\begin{tabular}{|c|c|c|c|c|}
\hline $\begin{array}{l}\text { HUTANG } \\
\text { LANCAR }\end{array}$ & & & & \\
\hline $\begin{array}{l}\text { Hutang Jangka } \\
\text { Pendek }\end{array}$ & & & & \\
\hline Dana Pendidikan & $153.039 .758,00$ & $161.354 .758,00$ & $8.315 .000,00$ & \\
\hline $\begin{array}{l}\text { Dana Pemb. Daerah } \\
\text { Kerja }\end{array}$ & $141.613 .286,00$ & $160.770 .806,00$ & $19.157 .520,00$ & \\
\hline Dana Sosial & $53.830 .070,00$ & $53.673 .090,00$ & & $156.980,00$ \\
\hline $\begin{array}{l}\text { Biaya yang Masih } \\
\text { Akan Dibyr }\end{array}$ & $52.396 .000,00$ & $53.353 .000,00$ & $957.000,00$ & \\
\hline $\begin{array}{l}\text { Jumlah Hutang J. } \\
\text { Pendek }\end{array}$ & 400.879.114,00 & 429.151.654,00 & & \\
\hline $\begin{array}{l}\text { Hutang Jangka } \\
\text { Panjang }\end{array}$ & & & & \\
\hline $\begin{array}{l}\text { Hutang Pembiayaan } \\
\text { BSM }\end{array}$ & $7.923 .019 .843,00$ & $6.327 .877 .750,00$ & & $1.095 .142 .093,00$ \\
\hline $\begin{array}{l}\text { Simpanan Khusus } \\
\text { Anggota }\end{array}$ & $2.250 .877 .481,00$ & 2.554.382.919,00 & $303.505 .438,00$ & \\
\hline $\begin{array}{l}\text { Jumlah Harta J. } \\
\text { Panjang }\end{array}$ & 10.173.897.324,00 & $8.882 .260 .669,00$ & & \\
\hline KEKAYAAN & & & & \\
\hline Simpanan Pokok & $46.486 .000,00$ & $47.603 .000,00$ & $1.117 .000,00$ & \\
\hline Simpanan Wajib & $440.960 .850,00$ & $464.688 .400,00$ & $23.727 .550,00$ & \\
\hline Donasi & $195.135 .132,00$ & $195.135 .132,00$ & 0,00 & \\
\hline Cadangan & $2.274 .591 .618,00$ & $2.581 .112 .006,00$ & $306.520 .388,00$ & \\
\hline SHU Tahun 2011 & $766.300 .817,00$ & & & $766.300 .817,00$ \\
\hline SHU Tahun 2012 & & $786.558 .737,00$ & $786.558 .737,00$ & \\
\hline Jumlah Kekayaan & 3.723.474.417,00 & $4.075 .097 .275,00$ & & \\
\hline $\begin{array}{l}\text { JUMLAH } \\
\text { HUTANG/PASIVA }\end{array}$ & 14.298.250.855,00 & 13.386.509.598,00 & & \\
\hline TOTAL & & & $2.956 .627 .478,00$ & $2.956 .627 .478,00$ \\
\hline
\end{tabular}

Sumber: Laporan Keuangan KSU “JUSI” (data diolah)

Tabel 7. Laporan Perubahan Modal Kerja KSU"JUSI" (Dalam Rupiah) Tahun 2011-2012

\begin{tabular}{|l|r|r|r|r|}
\hline \multirow{2}{*}{ KETERANGAN } & \multicolumn{2}{c|}{ TAHUN } & \multicolumn{1}{c|}{ PERUBAHAN MODAL } \\
\cline { 2 - 5 } & $\mathbf{2 0 1 1}$ & \multicolumn{1}{c|}{$\mathbf{2 0 1 2}$} & \multicolumn{1}{c|}{ NAIK } & \\
\hline HARTA LANCAR & & & & $410.416 .755,00$ \\
\hline Kas & $497.628 .980,00$ & $87.212 .225,00$ & & $279.381 .010,00$ \\
\hline Bank & $930.008 .331,00$ & $650.627 .321,00$ & & $390.406 .900,00$ \\
\hline Piutang & $12.571 .232 .230,00$ & $12.180 .825 .330,00$ & & \\
\hline $\begin{array}{l}\text { Cadangan Penyisihan } \\
\text { Piutang }\end{array}$ & $73.022 .040,00$ & $56.877 .366,00$ & $16.144 .674,00$ & $3.600 .000,00$ \\
\hline Piutang Akte Tanah & $5.000 .000,00$ & $1.400 .000,00$ & & $500.173,00$ \\
\hline Persediaan Barang & $35.997 .631,00$ & $35.497 .458,00$ & & \\
\hline $\begin{array}{l}\text { Persediaan Kapling } \\
\text { Tanah }\end{array}$ & $30.000 .000,00$ & $30.000 .000,00$ & - & \\
\hline
\end{tabular}




\section{Lanjutan Tabel 7. Laporan Perubahan Modal Kerja KSU “JUSI” (Dalam Rupiah)}

Tahun 2011-2012

\begin{tabular}{|l|r|r|r|r|}
\hline $\begin{array}{l}\text { Biaya Dibayar } \\
\text { Dimuka }\end{array}$ & $15.345 .500,00$ & $7.672 .750,00$ & & $7.672 .750,00$ \\
\hline $\begin{array}{l}\text { Jumlah Harta } \\
\text { Lancar }\end{array}$ & $\mathbf{1 4 . 0 1 2 . 1 9 0 . 6 3 2 , 0 0}$ & $\mathbf{1 2 . 9 3 6 . 3 5 7 . 7 1 8 , 0 0}$ & & \\
\hline & & & & \\
\hline HUTANG LANCAR & & & & \\
\hline $\begin{array}{l}\text { Hutang Jangka } \\
\text { Pendek }\end{array}$ & & & & \\
\hline Dana Pendidikan & $153.039 .758,00$ & $161.354 .758,00$ & $8.315 .000,00$ & \\
\hline $\begin{array}{l}\text { Dana Pemb. Daerah } \\
\text { Kerja }\end{array}$ & $141.613 .286,00$ & $160.770 .806,00$ & $19.157 .520,00$ & \\
\hline $\begin{array}{l}\text { Dana Sosial } \\
\text { Aiaya yang Masih } \\
\text { Akan Dibyr }\end{array}$ & $53.830 .070,00$ & $53.673 .090,00$ & & $156.980,00$ \\
\hline $\begin{array}{l}\text { Jumlah Hutang J. } \\
\text { Pendek }\end{array}$ & $\mathbf{5 2 . 3 9 6 . 0 0 0 , 0 0}$ & $53.353 .000,00$ & $957.000,00$ & \\
\hline $\begin{array}{l}\text { TOTAL } \\
\text { berkurangnya modal } \\
\text { kerja }\end{array}$ & & $\mathbf{4 2 9 . 1 5 1 . 6 5 4 , 0 0}$ & & \\
\hline & & & $44.574 .194,00$ & $236.813 .010,00$ \\
\hline
\end{tabular}

Sumber: Laporan Keuangan KSU “JUSI” (data diolah)

Tabel 8. Laporan Sumber dan Penggunaan Modal Kerja KSU “JUSI" (Dalam Rupiah) Tahun 2011-2012

\begin{tabular}{|l|r|l|r|}
\hline Sumber & Tunai & Penggunaan & Tunai \\
\hline penjualan kendaraan & $3.050 .000,00$ & $\begin{array}{l}\text { penambahan } \\
\text { bangunan }\end{array}$ & $141.362 .450,00$ \\
\hline $\begin{array}{l}\text { pelunasan hutang } \\
\text { pembiayaan BSM }\end{array}$ & $1.095 .141 .093,00$ & $\begin{array}{l}\text { pembelian peralatan } \\
\text { kantor }\end{array}$ & $3.666 .706,00$ \\
\hline $\begin{array}{l}\text { berkurangnya SHU Tahun } \\
2011\end{array}$ & $766.300 .817,00$ & $\begin{array}{l}\text { penambahan aktiva } \\
\text { lain-lain }\end{array}$ & $22.112 .500,00$ \\
\hline & & $\begin{array}{l}\text { bertambahnya simp. } \\
\text { Anggota }\end{array}$ & $303.505 .438,00$ \\
\hline & $\begin{array}{l}\text { bertambahnya } \\
\text { simp.pokok }\end{array}$ & $117.000,00$ \\
\hline & $\begin{array}{l}\text { bertambahnya } \\
\text { simp.wajib }\end{array}$ & $23.727 .550,00$ \\
\hline & $\begin{array}{l}\text { bertambahnya dana } \\
\text { cadangan }\end{array}$ & $306.520 .388,00$ \\
\hline & $\begin{array}{l}\text { kerugian SHU tahun } \\
\text { 2012 }\end{array}$ & $786.558 .737,00$ \\
\hline TOTAL & & TOTAL & $\mathbf{3 . 1 2 1 . 9 8 9 . 7 3 1 , 0 0}$ \\
\hline Berkurangnya modal kerja & $\mathbf{1 9 2 . 2 3 8 . 8 1 6 , 0 0}$ & & $3.121 .989 .731,00$ \\
\hline & $3.121 .989 .731,00$ & & \\
\hline
\end{tabular}

Sumber: Laporan Keuangan KSU “JUSI” (data diolah) 
Tabel 9. Laporan Perubahan Posisi Keuangan KSU “JUSI" (Dalam Rupiah)

Tahun 2012-2013

\begin{tabular}{|c|c|c|c|c|}
\hline \multirow{2}{*}{ KETERANGAN } & \multicolumn{2}{|c|}{ TAHUN } & \multicolumn{2}{|c|}{ PERUBAHAN } \\
\hline & 2012 & 2013 & DEBIT & KREDIT \\
\hline \multicolumn{5}{|l|}{ HARTA LANCAR } \\
\hline Kas & $87.212 .225,00$ & $172.272 .750,00$ & $85.060 .525,00$ & \\
\hline Bank & $650.627 .321,00$ & $330.707 .708,00$ & & $319.919 .613,00$ \\
\hline Piutang & $12.180 .825 .330,00$ & $10.261 .963 .474,00$ & & $1.918 .861 .856,00$ \\
\hline $\begin{array}{l}\text { Cadangan } \\
\text { Penyisihan Piutang }\end{array}$ & $56.877 .366,00$ & $56.385 .116,00$ & $492.250,00$ & \\
\hline Piutang Akte Tanah & $1.400 .000,00$ & $1.200 .000,00$ & & $200.000,00$ \\
\hline Persediaan Barang & $35.497 .458,00$ & $34.258 .308,00$ & & $1.239 .150,00$ \\
\hline $\begin{array}{l}\text { Persediaan Kapling } \\
\text { Tanah }\end{array}$ & $30.000 .000,00$ & $30.000 .000,00$ & 0,00 & \\
\hline $\begin{array}{l}\text { Biaya Dibayar } \\
\text { Dimuka }\end{array}$ & $7.672 .750,00$ & & & $7.672 .750,00$ \\
\hline $\begin{array}{l}\text { Jumlah Harta } \\
\text { Lancar }\end{array}$ & 12.936.357.718,00 & 10.774.017.124,00 & & \\
\hline \multicolumn{5}{|l|}{ HARTA TETAP } \\
\hline Tanah & $70.000 .000,00$ & $70.000 .000,00$ & 0,00 & \\
\hline Bangunan & $185.367 .898,00$ & $184.511 .624,00$ & & $856.274,00$ \\
\hline Kendaraan & $3.750 .008,00$ & 5,00 & & $3.750 .003,00$ \\
\hline $\begin{array}{l}\text { Peralatan Kantor } \\
\text { dan Toko }\end{array}$ & $125.508 .974,00$ & $120.067 .090,00$ & & $5.441 .884,00$ \\
\hline Aktiva lain-lain & $65.525 .000,00$ & $56.387 .501,00$ & & $9.137 .499,00$ \\
\hline Jumlah Harta Tetap & 450.151.880,00 & 430.966.220,00 & & \\
\hline $\begin{array}{l}\text { JUMLAH } \\
\text { HARTA/AKTIVA }\end{array}$ & 13.386.509.598,00 & 11.204.983.344,00 & & \\
\hline \multicolumn{5}{|l|}{ HUTANG LANCAR } \\
\hline \multicolumn{5}{|l|}{$\begin{array}{l}\text { Hutang Jangka } \\
\text { Pendek }\end{array}$} \\
\hline Dana Pendidikan & $161.354 .758,00$ & $170.682 .693,00$ & $9.327 .935,00$ & \\
\hline $\begin{array}{l}\text { Dana Pemb. Daerah } \\
\text { Kerja }\end{array}$ & $160.770 .806,00$ & $180.434 .277,00$ & $19.663 .471,00$ & \\
\hline Dana Sosial & $53.673 .090,00$ & $51.627 .561,00$ & & $2.045 .529,00$ \\
\hline $\begin{array}{l}\text { Biaya yang Masih } \\
\text { Akan Dibyr }\end{array}$ & $53.353 .000,00$ & $51.750 .000,00$ & & $1.603 .000,00$ \\
\hline $\begin{array}{l}\text { Jumlah Hutang J. } \\
\text { Pendek }\end{array}$ & 429.151.654,00 & 454.494.531,00 & & \\
\hline \multicolumn{5}{|l|}{$\begin{array}{l}\text { Hutang Jangka } \\
\text { Panjang }\end{array}$} \\
\hline $\begin{array}{l}\text { Hutang Pembiayaan } \\
\text { BSM }\end{array}$ & $6.327 .877 .750,00$ & $3.499 .112 .690,00$ & & $2.828 .765 .060,00$ \\
\hline $\begin{array}{l}\text { Simpanan Khusus } \\
\text { Anggota }\end{array}$ & 2.554.382.919,00 & $2.864 .852 .264,00$ & $310.469 .345,00$ & \\
\hline $\begin{array}{l}\text { Jml Hutang J. } \\
\text { Panjang }\end{array}$ & 8.882.260.669,00 & 6.363.964.954,00 & & \\
\hline
\end{tabular}




\section{Lanjutan Tabel 9. Laporan Perubahan Posisi Keuangan KSU “JUSI" (Dalam Rupiah)}

Tahun 2012-2013

\begin{tabular}{|l|r|r|r|r|}
\hline KEKAYAAN & & & & \\
\hline Simpanan Pokok & $47.603 .000,00$ & $48.139 .000,00$ & $536.000,00$ & \\
\hline Simpanan Wajib & $464.688 .400,00$ & $483.701 .050,00$ & $19.012 .650,00$ & \\
\hline Donasi & $195.135 .132,00$ & $195.135 .132,00$ & 0,00 & \\
\hline Cadangan & $2.581 .112 .006,00$ & $2.895 .736 .001,00$ & $314.623 .995,00$ & \\
\hline SHU Tahun 2012 & $786.558 .737,00$ & & & $786.558 .737,00$ \\
\hline SHU Tahun 2013 & & $763.812 .676,00$ & $763.812 .676,00$ & \\
\hline Jumlah Kekayaan & $\mathbf{4 . 0 7 5 . 0 9 7 . 2 7 5 , 0 0}$ & $\mathbf{4 . 3 8 6 . 5 2 3 . 8 5 9 , 0 0}$ & & \\
\hline $\begin{array}{l}\text { JUMLAH } \\
\text { HUTANG/PASIVA }\end{array}$ & $\mathbf{1 3 . 3 8 6 . 5 0 9 . 5 9 8 , 0 0}$ & $\mathbf{1 1 . 2 0 4 . 9 8 3 . 3 4 4 , 0 0}$ & & \\
\hline TOTAL & & & $5.886 .051 .355,00$ & $5.886 .051 .355,00$ \\
\hline
\end{tabular}

Sumber: Laporan Keuangan KSU “JUSI” (data diolah)

Tabel 10. Laporan Perubahan Modal Kerja KSU “JUSI” (Dalam Rupiah) Periode 2012-2013)

\begin{tabular}{|c|c|c|c|c|}
\hline \multirow{2}{*}{ KETERANGAN } & \multicolumn{2}{|c|}{ TAHUN } & \multicolumn{2}{|c|}{ PERUBAHAN MODAL KERJA } \\
\hline & 2012 & 2013 & NAIK & TURUN \\
\hline \multicolumn{5}{|l|}{$\begin{array}{l}\text { HARTA } \\
\text { LANCAR }\end{array}$} \\
\hline Kas & $87.212 .225,00$ & $172.272 .750,00$ & $85.060 .525,00$ & \\
\hline Bank & $650.627 .321,00$ & $330.707 .708,00$ & & $319.919 .613,00$ \\
\hline Piutang & $12.180 .825 .330,00$ & $10.261 .963 .474,00$ & & $1.918 .861 .856,00$ \\
\hline $\begin{array}{l}\text { Cadangan } \\
\text { Penyisihan } \\
\text { Piutang }\end{array}$ & $56.877 .366,00$ & $56.385 .116,00$ & $492.250,00$ & \\
\hline $\begin{array}{l}\text { Piutang Akte } \\
\text { Tanah }\end{array}$ & $1.400 .000,00$ & $1.200 .000,00$ & & $200.000,00$ \\
\hline Persediaan Barang & $35.497 .458,00$ & $34.258 .308,00$ & & $1.239 .150,00$ \\
\hline $\begin{array}{l}\text { Persediaan } \\
\text { Kapling Tanah }\end{array}$ & $30.000 .000,00$ & $30.000 .000,00$ & 0,00 & \\
\hline $\begin{array}{l}\text { Biaya Dibayar } \\
\text { Dimuka }\end{array}$ & $7.672 .750,00$ & & & 7.672.750,00 \\
\hline $\begin{array}{l}\text { Jumlah Harta } \\
\text { Lancar }\end{array}$ & 12.936.357.718,00 & 10.774.017.124,00 & & \\
\hline \multicolumn{5}{|l|}{ HUTANG LANCAR } \\
\hline $\begin{array}{l}\text { Hutang Jangka } \\
\text { Pendek }\end{array}$ & & & & \\
\hline Dana Pendidikan & $161.354 .758,00$ & $170.682 .693,00$ & $9.327 .935,00$ & \\
\hline $\begin{array}{l}\text { Dana Pemb. } \\
\text { Daerah Kerja }\end{array}$ & $160.770 .806,00$ & $180.434 .277,00$ & 19.663.471,00 & \\
\hline Dana Sosial & $53.673 .090,00$ & $51.627 .561,00$ & & $2.045 .529,00$ \\
\hline $\begin{array}{l}\text { Biaya yang Masih } \\
\text { Akan Dibyr }\end{array}$ & $53.353 .000,00$ & $51.750 .000,00$ & & $1.603 .000,00$ \\
\hline $\begin{array}{l}\text { Jumlah Hutang } \\
\text { J. Pendek }\end{array}$ & 429.151.654,00 & 454.494.531,00 & & \\
\hline JUMLAH & & & $114.544 .181,00$ & $2.251 .541 .898,00$ \\
\hline Penurunan Modal & & & $2.136 .997 .717,00$ & \\
\hline TOTAL & & & $2.251 .541 .898,00$ & \\
\hline
\end{tabular}

Sumber: Laporan Keuangan KSU “JUSI” (data diolah)

24 Jurnal Fidusia, Volume 2 Nomor 1 - April 2019 
Tabel 11. Laporan Sumber dan Penggunaan Modal Kerja KSU “JUSI" (Dalam Rupiah) 2012-2013

\begin{tabular}{|l|r|l|r|}
\hline \multicolumn{1}{|c|}{ SUMBER } & \multicolumn{1}{c|}{ TUNAI } & \multicolumn{1}{c|}{ PENGGUNAAN } & \multicolumn{1}{c|}{ TUNAI } \\
\hline Bertambahnya Barang cetakan & $856.274,00$ & $\begin{array}{l}\text { berkurangnya simp. } \\
\text { Khusus anggota }\end{array}$ & $310.469 .345,00$ \\
\hline Penjualan Kendaraan & $3.750 .003,00$ & $\begin{array}{l}\text { bertambhnya simp. } \\
\text { Pokok }\end{array}$ & $536.000,00$ \\
\hline penjualan peralatan kantor & $5.441 .884,00$ & $\begin{array}{l}\text { bertambahnya simp. } \\
\text { Wajib }\end{array}$ & $19.012 .650,00$ \\
\hline berkurangnya aktiva lain-lain & $9.137 .499,00$ & $\begin{array}{l}\text { bertambhnya modal } \\
\text { cadangan }\end{array}$ & $314.623 .995,00$ \\
\hline Pelunasan hutang BSM & $2.828 .765 .060,00$ & bertambahnya bangunan & $4.363 .052 .508,00$ \\
\hline Penurunan SHU Tahun 2012 & $786.558 .737,00$ & SHU Tahun 2013 & $763.812 .676,00$ \\
\hline Jumlah & $3.634 .509 .457,00$ & Jumlah & $5.771 .507 .174,00$ \\
\hline penurunan modal & $2.136 .997 .717,00$ & & \\
\hline TOTAL & $5.771 .507 .174,00$ & TOTAL & $5.771 .507 .174,00$ \\
\hline
\end{tabular}

Sumber: Laporan Keuangan KSU "JUSI" (data diolah)

Tabel 12. Laporan Perubahan Posisi Keuangan KSU “JUSI” (Dalam Rupiah) 2013-2014

\begin{tabular}{|c|c|c|c|c|}
\hline \multirow{2}{*}{ KETERANGAN } & \multicolumn{2}{|c|}{ TAHUN } & \multicolumn{2}{|c|}{ PERUBAHAN } \\
\hline & 2013 & 2014 & DEBIT & KREDIT \\
\hline \multicolumn{5}{|l|}{ HARTA LANCAR } \\
\hline Kas & $172.272 .750,00$ & $194.362 .575,00$ & $22.089 .825,00$ & \\
\hline Bank & $330.707 .708,00$ & $481.099 .068,00$ & $150.391 .360,00$ & \\
\hline Piutang & $10.261 .963 .474,00$ & $8.186 .943 .662,00$ & & $2.075 .019 .812,00$ \\
\hline $\begin{array}{l}\text { Cadangan Penyisihan } \\
\text { Piutang }\end{array}$ & $56.385 .116,00$ & $56.385 .116,00$ & 0,00 & \\
\hline Piutang Akte Tanah & $1.200 .000,00$ & $1.200 .000,00$ & 0,00 & \\
\hline Persediaan Barang & $34.258 .308,00$ & $34.046 .818,00$ & & $211.490,00$ \\
\hline $\begin{array}{l}\text { Persediaan Kapling } \\
\text { Tanah }\end{array}$ & $30.000 .000,00$ & $30.000 .000,00$ & 0,00 & \\
\hline Jumlah Harta Lancar & 10.774.017.124,00 & $8.871 .267 .007,00$ & & \\
\hline \multicolumn{5}{|l|}{ HARTA TETAP } \\
\hline Tanah & $70.000 .000,00$ & $70.000 .000,00$ & 0,00 & \\
\hline Bangunan & $184.511 .624,00$ & $170.263 .550,00$ & & $14.248 .074,00$ \\
\hline Kendaraan & 5,00 & 5,00 & 0,00 & \\
\hline $\begin{array}{l}\text { Peralatan Kantor dan } \\
\text { Toko }\end{array}$ & $120.067 .090,00$ & $88.340 .194,00$ & & $31.726 .896,00$ \\
\hline Aktiva lain-lain & $56.387 .501,00$ & $48.050 .002,00$ & & $8.337 .499,00$ \\
\hline Jumlah Harta Tetap & 430.966.220,00 & 376.653.751,00 & & \\
\hline $\begin{array}{l}\text { JUMLAH } \\
\text { HARTA/AKTIVA }\end{array}$ & 11.204.983.344,00 & $9.247 .920 .758,00$ & & \\
\hline
\end{tabular}


Lanjutan Tabel 12. Laporan Perubahan Posisi Keuangan KSU "JUSI" (Dalam Rupiah) 2013-2014

\begin{tabular}{|l|r|r|r|r|}
\hline HUTANG LANCAR & & & \\
\hline Hutang Jangka Pendek & & & & \\
\hline Dana Pendidikan & $170.682 .693,00$ & $178.873 .293,00$ & $8.190 .600,00$ & \\
\hline $\begin{array}{l}\text { Dana Pemb. Daerah } \\
\text { Kerja }\end{array}$ & $180.434 .277,00$ & $199.529 .645,00$ & $19.095 .368,00$ & \\
\hline Dana Sosial & $51.627 .561,00$ & $54.872 .929,00$ & $3.245 .368,00$ & \\
\hline $\begin{array}{l}\text { Biaya yang Masih Akan } \\
\text { Dibyr }\end{array}$ & $51.750 .000,00$ & $42.183 .000,00$ & & \\
\hline $\begin{array}{l}\text { Jumlah Hutang J. } \\
\text { Pendek }\end{array}$ & $\mathbf{4 5 4 . 4 9 4 . 5 3 1 , 0 0}$ & $\mathbf{4 7 5 . 4 5 8 . 8 6 7 , 0 0}$ & & \\
\hline Hutang Jangka Panjang & & & & \\
\hline $\begin{array}{l}\text { Hutang Pembiayaan } \\
\text { BSM }\end{array}$ & $3.499 .112 .690,00$ & $1.035 .958 .519,00$ & & \\
\hline $\begin{array}{l}\text { Simpanan Khusus } \\
\text { Anggota }\end{array}$ & $2.864 .852 .264,00$ & $3.169 .222 .234,00$ & $304.369 .970,00$ & \\
\hline $\begin{array}{l}\text { Jumlah Hutang J. } \\
\text { Panjang }\end{array}$ & $\mathbf{6 . 3 6 3 . 9 6 4 . 9 5 4 , 0 0}$ & $\mathbf{4 . 2 0 5 . 1 8 0 . 7 5 3 , 0 0}$ & & \\
\hline & & & & \\
\hline KEKAYAAN & & & & \\
\hline Simpanan Pokok & $48.139 .000,00$ & $48.163 .000,00$ & & \\
\hline Simpanan Wajib & $483.701 .050,00$ & $499.555 .400,00$ & $15.854 .350,00$ & \\
\hline Donasi & $195.135 .132,00$ & $195.135 .132,00$ & & 0,00 \\
\hline Cadangan & $2.895 .736 .001,00$ & $3.201 .261 .071,00$ & $305.525 .070,00$ & \\
\hline SHU Tahun 2013 & $763.812 .676,00$ & & & $763.171,00$ \\
\hline SHU Tahun 2014 & $\mathbf{4 . 3 8 6 . 5 2 3 . 8 5 9 , 0 0}$ & $\mathbf{4 . 5 6 7 . 2 8 1 . 1 3 8 , 0 0}$ & & \\
\hline Jumlah Kekayaan & $\mathbf{1 1 . 2 0 4 . 9 8 3 . 3 4 4 , 0 0}$ & $\mathbf{9 . 2 4 7 . 9 2 0 . 7 5 8 , 0 0}$ & & \\
\hline $\begin{array}{l}\text { JUMLAH } \\
\text { HUTANG/PASIVA }\end{array}$ & & & $5.366 .077 .618,00$ & $5.366 .077 .618,00$ \\
\hline TOTAL & & & \\
\hline
\end{tabular}

Sumber: Laporan Keuangan KSU “JUSI” (data diolah)

Tabel 13 Laporan Perubahan Modal Kerja Koperasi Serba Usaha Jurai Siwo

(Dalam Rupiah) Periode 2013-2014

\begin{tabular}{|l|r|r|r|r|}
\hline \multirow{2}{*}{ KETERANGAN } & \multicolumn{2}{|c|}{ TAHUN } & \multicolumn{1}{c|}{ PERUBAHAN MODAL KERJA } \\
\cline { 2 - 5 } & \multicolumn{1}{|c|}{$\mathbf{2 0 1 3}$} & $\mathbf{2 0 1 4}$ & \multicolumn{1}{c|}{ NAIK } & \multicolumn{1}{c|}{ TURUN } \\
\hline HARTA LANCAR & & & & \\
\hline Kas & $172.272 .750,00$ & $194.362 .575,00$ & $22.089 .825,00$ & \\
\hline Bank & $330.707 .708,00$ & $481.099 .068,00$ & $150.391 .360,00$ & \\
\hline Piutang & $10.261 .963 .474,00$ & $8.186 .943 .662,00$ & & \\
\hline $\begin{array}{l}\text { Cadangan Penyisihan } \\
\text { Piutang }\end{array}$ & $56.385 .116,00$ & $56.385 .116,00$ & 0,00 & \\
\hline Piutang Akte Tanah & $1.200 .000,00$ & $1.200 .000,00$ & 0,00 & \\
\hline Persediaan Barang & $34.258 .308,00$ & $34.046 .818,00$ & & \\
\hline $\begin{array}{l}\text { Persediaan Kapling } \\
\text { Tanah }\end{array}$ & $30.000 .000,00$ & $30.000 .000,00$ & & \\
\hline $\begin{array}{l}\text { Jumlah Harta } \\
\text { Lancar }\end{array}$ & $\mathbf{1 0 . 7 7 4 . 0 1 7 . 1 2 4 , 0 0}$ & $\mathbf{8 . 8 7 1 . 2 6 7 . 0 0 7 , 0 0}$ & & \\
\hline
\end{tabular}


Lanjutan Tabel 13. Laporan Perubahan Modal Kerja Koperasi Serba Usaha Jurai Siwo (Dalam Rupiah) Periode 2013-2014

\begin{tabular}{|l|r|r|r|r|}
\hline HUTANG LANCAR & & & & \\
\hline $\begin{array}{l}\text { Hutang Jangka } \\
\text { Pendek }\end{array}$ & & & & \\
\hline Dana Pendidikan & $170.682 .693,00$ & $178.873 .293,00$ & $8.190 .600,00$ & \\
\hline $\begin{array}{l}\text { Dana Pemb. Daerah } \\
\text { Kerja }\end{array}$ & $180.434 .277,00$ & $199.529 .645,00$ & $19.095 .368,00$ & \\
\hline Dana Sosial & $51.627 .561,00$ & $54.872 .929,00$ & $3.245 .368,00$ & \\
\hline $\begin{array}{l}\text { Biaya yang Masih } \\
\text { Akan Dibyr }\end{array}$ & $51.750 .000,00$ & $42.183 .000,00$ & & \\
\hline $\begin{array}{l}\text { Jumlah Hutang J. } \\
\text { Pendek }\end{array}$ & $\mathbf{4 5 4 . 4 9 4 . 5 3 1 , 0 0}$ & $\mathbf{4 7 5 . 4 5 8 . 8 6 7 , 0 0}$ & & \\
\hline $\begin{array}{l}\text { JUMLAH } \\
\text { HUTANG/PASIVA }\end{array}$ & $\mathbf{1 1 . 2 0 4 . 9 8 3 . 3 4 4 , 0 0}$ & $\mathbf{9 . 2 4 7 . 9 2 0 . 7 5 8 , 0 0}$ & & \\
\hline Jumlah & & & $203.012 .521,00$ & $2.084 .000,00$ \\
\hline $\begin{array}{l}\text { Penurunan modal } \\
\text { kerja }\end{array}$ & & & $1.881 .785 .781,00$ & \\
\hline Total & & & $2.084 .798 .302,00$ & \\
\hline
\end{tabular}

Sumber: Laporan Keuangan KSU “JUSI” (data diolah)

Tabel 14. Laporan Sumber dan Penggunaan Modal Kerja Koperasi Serba Usaha Jurai Siwo (Dalam Rupiah) Periode 2013-2014

\begin{tabular}{|l|r|l|r|}
\hline \multicolumn{1}{|c|}{ SUMBER } & \multicolumn{1}{c|}{ TUNAI } & \multicolumn{1}{c|}{ PENGGUNAAN } & \multicolumn{1}{c|}{ TUNAI } \\
\hline Penjualan gedung bangunan & $14.248 .074,00$ & $\begin{array}{l}\text { bertmbahnya anggota } \\
\text { simp. Khusus }\end{array}$ & $304.369 .970,00$ \\
\hline Penjualan peralatan kntor dan toko & $31.726 .896,00$ & renovasi & 1914125172 \\
\hline Berkurangnya aktiva lain-lain & $8.337 .499,00$ & $\begin{array}{l}\text { pembelian inventaris } \\
\text { kantor }\end{array}$ & $24.000,00$ \\
\hline Pelunasan hutang BSM & $2.463 .154 .171,00$ & $\begin{array}{l}\text { bertambahnya simp. } \\
\text { Pokok }\end{array}$ & $15.854 .350,00$ \\
\hline Penurunan SHU Tahun 2013 & $763.812 .676,00$ & $\begin{array}{l}\text { bertambahnya simp. } \\
\text { Wajib }\end{array}$ & $305.525 .070,00$ \\
\hline & & $\begin{array}{l}\text { bertambahnya dana } \\
\text { cadangan }\end{array}$ & $623.166 .535,00$ \\
\hline Jumlah & & SHU TAHUN 2014 & 5.163 .065 .097 \\
\hline penurunan modal kerja & $\mathbf{3 . 2 8 1 . 2 7 9 . 3 1 6 , 0 0}$ & JUMLAH & $\mathbf{5 . 1 6 3 . 0 6 5 . 0 9 7}$ \\
\hline Total & $1.881 .785 .781,00$ & & \\
\hline
\end{tabular}

Sumber: Laporan Keuangan KSU “JUSI” (data diolah) 
Tabel 4.3. menunjukkan bahwa dalam periode 2010-2011 KSU "JUSI" mengalami kenaikan modal kerja sebesar Rp. 136.250.257,00 yang disebabkan perolehan sumber modal kerja yang lebih besar dibandingkan penggunaan modal kerja. Sumber modal kerja yang terbesar yaitu dari penurunan SHU Tahun 2011 Rp. 729.873.299,00 sebesar Rp. 766.300.817,00

Tabel 4.6. menunjukkan bahwa periode 2011-2012 KSU "JUSI" mengalami penurunan modal kerja sebesar Rp. 192.238.816,00 yang disebabkan penggunaan modal kerja lebih besar dibandingkan dengan sumber modal kerja. Penggunaan modal kerja yang terbesar yaitu kerugian SHU Tahun 2012 sebesar Rp. 786.558.737,00

Tabel 4.9. diatas menunjukkan bahwa dalam periode 2012-2013 KSU “JUSI" mengalami penurunan modal kerja kembali sebesar Rp. 2.136.997.717,00 yang disebabkan penggunaan modal kerja lebih besar dibandingkan dengan sumber modal kerja.

Tabel 4.12 diatas menunjukkan bahwa dalam periode 2013-2014 KSU “JUSI" mengalami penurunan modal kerja sebesar Rp. 1.881.785.781,00 yang disebabkan penggunaan modal kerja lebih besar dibandingkan sumber modal kerja.

Dari hasil penelitian Yunies Rochmawati Dengan Judul "Analisis Sumber dan penggunaan modal kerja (studi pada KSU Modjopanggoong Tulung Agung)". Dapat dijelaskan bahwa sumber dan penggunaan modal kerja KSU Mudjopanggoong mengalami penurunan modal kerja pada tahun 2002-2003 yg disebabkan penggunaan modal lebih besar dari pada sumbernya. Dan pada tahun 2003-2004 mengalami kenaikan modal kerja hal ini dilihat dari sumber yang diperoleh lebih besar dari penggunaannya. Yg berasal dari laba operasi.

Berdasarkan hasil penelitian pada "KSU" Jurai Siwo pada Tabel 4.3. laporan sumber dan penggunaan modal kerja pada periode 2010-2011 sumber modal yang utama yakni SHU Tahun 2011 sebesar Rp.766.300.817,00 dan berkurangnya simpanan wajib sebesar Rp.375.209.400,00 sedangkan sumber modal yang terendah berasal dari berkurangnya simpanan pokok sebesar Rp. 1.195.000,00. Penggunaan modal kerja yang paling besar adalah penurunan SHU Tahun 2010 dan disusul oleh pelunasan hutang BSM sebesar Rp. 931.791.904,00. Hal ini yang menyebabkan terjadinya sumber modal terlalu besar yang tidak diimbangi dengan penggunaan modal sehingga menyebabkan dana menganggur.

Pada periode 2011-2012 yang berdasarkan Tabel 4.6. sumber modal kerja berasal dari penjualan kendaraan sebesar Rp. 3.050.000,00 dan dari hasil operasi KSU “JUSI” sebesar Rp. 766.300.817,00 sumber modal yang utama berasal dari hutang pembiayaan BSM sebesar Rp. 1.095.141.093,00 . penggunaan modal kerja yang utama berasal dari kerugian SHU Tahun 2012 sebesar Rp. 786.558.737. untuk menutupi kerugian yang di alami KSU “JUSI” pimpinan menjual beberapa kendaraannya dan meningkatkan hasil operasional perusahaan.

Tabel 4.9. terlihat bahwa pada periode 2012-2013 sumber modal yang mendominasi adalah pelunasan hutang BSM sebesar Rp. 2.828.765.060,00 dan disusul oleh SHU Tahun 2012 sebesar Rp. 786.558.737,00 sumber modal yang terendah berasal dari penjualan barang cetakan sebesar Rp. 856.274,00. Penggunaan modal kerja yang terbesar berasal karena bertambahnya bangunan sebesar 
Rp. 4.363.052.508,00 dan kerugian SHU Tahun 2013 sebesar

Rp. 763.812.676,00. Karena pimpinan berupaya untuk mengembangkan perusahaannya dengan menambah gedung bangunan secara berlebihan sehingga menyebabkan penurunan modal kerja sebesar Rp. 2.136.997.717,00

Pada periode tahun 2013-2014 dari tabel 4.12 terlihat bahwa sumber modal yang utama berasal dari pelunasan hutang BSM sebesar Rp. 2.463.154.171 sedangkan sumber modal yang terendah berasal dari berkurangnya aktiva lain-lain sebesar Rp. 8.337.499,00. Penggunaan modal yang terbesar perenovasian bangunan sebesar Rp. 2.000.000.000,00 dan kerugian tahun 2014. Terlihat bahwa pimpinan berupaya untuk merapikan bangunan/renovasi dan mengalami kerugian sehingga perusahaan mengalami penurunan modal kerja kembali sebesar Rp. 1.881.785

\section{KESIMPULAN}

Berdasarkan hasil analisis dapat disimpulkan sebagai berikut:

1. Berdasarkan hasil analisis laporan sumber dan penggunaan modal kerja pada KSU "JUSI" pada periode 2010-2011 ternyata mengalami kenaikan modal kerja sebesar Rp. 136.250.257,0. Pada periode 2011-2012 mengalami penurunan modal kerja sebesar Rp. 192.238.816,00. Pada periode 2012-2013 KSU “JUSI" mengalami penurunan modal kerja kembali sebesar Rp. 2.136.997.717,00. KSU “JUSI" pada periode 2013-2014 mengalami penurunan modal kerja sebesar Rp. 1.881.785.781,00

2. Analisis laporan sumber dan penggunaan modal kerja pada KSU "JUSI" perubahan-perubahan yang terjadi pada posisi modal kerja periode 2010-2011 yakni SHU Tahun 2011 sebesar Rp. 766.300.817,00 dan sumber modal yang terendah berasal dari berkurangnya simpanan pokok sebesar Rp. 1.195.000,00. Penggunaan modal kerja yang paling besar adalah penurunan SHU Tahun 2010 Rp. 729.873.299,00 dan disusul oleh pelunasan hutang BSM sebesar Rp. 931.791.904,00. Pada periode 2011-2012 sumber modal kerja berasal dari penjualan kendaraan sebesar Rp. 3.050.000,00 dan dari hasil operasi KSU “JUSI” sebesar Rp. 766.300.817,00 sumber modal yang utama berasal dari hutang pembiayaan BSM sebesar Rp. 1.095.141.093,00 - penggunaan modal kerja yang utama berasal dari kerugian SHU Tahun 2012 sebesar Rp. 786.558.737. Periode 2012-2013 sumber modal yang mendominasi adalah pelunasan hutang BSM sebesar Rp. 2.828.765.060,00 Penggunaan modal kerja yang terbesar berasal karena bertambahnya bangunan dan inventaris kantor sebesar Rp. 4.363.052.508,00 dan kerugian SHU Tahun 2013 sebesar Rp. 763.812.676,00. Pada periode tahun 2013-2014 sumber modal berasal dari pelunasan hutang BSM sebesar Rp. 2.463.154.171 sedangkan sumber modal yang terendah berasal dari berkurangnya aktiva lain-lain sebesar Rp. 8.337.499,00. Penggunaan modal yang terbesar perenovasian bangunan dan pembaharuan peralatan kantor sebesar Rp. 2.000.000.000,00 dan kerugian tahun sebelumnya. 
Pengelolaan sumber modal kerja, hendaknya perusahaan lebih mengoptimalkan sumber modal yang ada. Mengingat manajemen modal kerja yang baik adalah besarnya modal kerja yang harus sesuai dengan penggunaan modal untuk menjamin keberlangsungan perusahaan agar tidak terjadi penurunan laba perusahaan di tahun berikutnya. Koperasi serba usaha jurai siwo memiliki pengelolaan modal kerja yang kurang baik, hal ini sebenarnya merugikan bagi koperasi maka sebaiknya dalam melakukan kegiatan operasional koperasi harus mempertimbangkan besarnya dana yang ada.

\section{DAFTAR PUSTAKA}

Kasmir. 2012. Analisis Manajemen Keuangan. Penerbit Raja Grafindo.

Munawir S. 2004. Analisis laporan keuangan. Penerbit liberty, Yogyakarta.

Riyanto, Bambang. 2010. Dasar-Dasar Pembelanjaan Perusahaan, Edisi 4. BPFE Universitas Gajah Mada, Yogyakarta.

Teguh Sihono. 1999. Pengantar Ekonomi Koperasi.

Tunggal Amin Widjaja. 2000.Dasar-dasar Analisis Laporan Keuangan. Rineka Cipta, Jakarta.

Undang-Undang Republik Indonesia No. 17 Tahun.2012 Tentang Pengkoperasian. (www.hukumonline.com) 